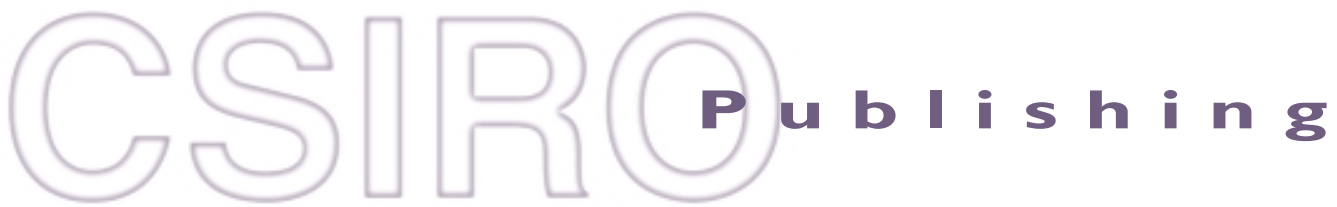

\section{Australian JOURNAL of B O T A N Y}

Volume 49, 2001

(c) CSIRO 2001

AN INTERNATIONAL JOURNAL FOR

THE PUBLICATION OF ORIGINAL

RESEARCH IN PLANT SCIENCE

All enquiries and manuscripts should be directed to:

Australian Journal of Botany

CSIRO Publishing

PO Box 1139 (150 Oxford St)

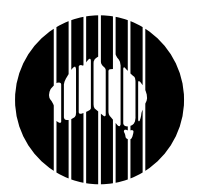

Collingwood, Vic. 3066, Australia

Telephone: +6139662 7613

Fax: +6139662 7611

C S I RO

Email: publishing.ajb@csiro.au

Published by CSIRO Publishing

for CSIRO and the Australian Academy of Science

www.publish.csiro.au/journals/ajb 


\title{
Anatomical studies of shoot bud-forming roots of Brazilian tree species
}

\author{
A. H. Hayashi ${ }^{\mathrm{A}}$, A. S. Penha ${ }^{\mathrm{A}}$, R. R. Rodrigues ${ }^{\mathrm{B}}$ and B. Appezzato-da-Glória ${ }^{\mathrm{BC}}$ \\ ${ }^{A}$ Departamento de Botânica, Instituto de Biologia, Universidade Estadual de Campinas, \\ Caixa Postal 6109, 13081-970, Campinas, São Paulo, Brazil. \\ ${ }^{B}$ Departamento de Ciências Biológicas, Escola Superior de Agricultura 'Luiz de Queiroz', Universidade de São \\ Paulo, Caixa Postal 09, 13418-900, Piracicaba, São Paulo, Brazil. \\ ${ }^{\mathrm{C}}$ Corresponding author; bagloria@carpa.ciagri.usp.br
}

\begin{abstract}
The present study is the first confirmation of the presence of shoot sprouts on roots in tree species of the Brazilian tropical forest, as these underground systems are usually only analysed by external gross morphological observations. The shoot-bearing roots of seven species, collected in a forest block frequently affected by fire, were sectioned and analysed for the number of primary xylem ridges, stele type and reserve compounds. Starch was the predominant reserve compound and occurred in different quantities among the species. The epicormic shoot buds, which arise spontaneously on root cuttings or plants subjected to fire, were analysed in two of the studied species. These buds showed different sites of origin but were considered epicormic (reparative) since they did not carry bud traces along the secondary xylem during their early development. Shoot bud formation on root systems is generally associated with disturbed environments, and confirmation that sprouting from roots does occur may modify many aspects of our appreciation of the community dynamics of forest species and models that define how we manage and rehabilitate Brazilian forest fragments.
\end{abstract}

\section{Introduction}

Several woody species are able to form shoot sprouts by initiation de novo of adventitious buds on their lateral roots (Lacey and Johnston 1990). However, this phenomenon is much more common among herbaceous species, particularly a number of weedy species (Raju et al. 1966; Polowick and Raju 1982; Baird et al. 1992). Generally, the formation of shoot buds on roots is associated with species that are subjected to some type of environmental disturbance (Rizzini and Heringer 1966; Lacey and Johnston 1990).

Although the formation of shoot buds on roots in temperate forest tree species is considered a common event and of vital importance in the maintenance and dynamics of these forests (Rood et al. 1994), this phenomenon has only recently been reported for tropical Brazilian forests (Castellani and Stubblebine 1993; Penha 1998). Roots capable of forming shoot buds as described by Rizzini and Heringer (1961) have been studied only on the basis of external morphological features of the underground systems, whereas detailed anatomical studies are needed before verifying the root-like structure of such systems (Raju et al. 1966; Rizzini and Heringer 1966). In some publications (e.g. Bosela and Ewers 1997) the structures concerned are referred to as 'root buds' and the distinction is made between those that form naturally on undamaged plants ('additional' or 'constitutive' buds) and those initiated only after disturbance ('reparative' or 'epicormic' buds). Anatomical studies on the origin and development of shoot buds on roots are also extremely important for a better understanding of the ecological and physiological responses of species which possess roots with this propensity.

The anatomical analyses carried out in the present study were aimed at obtaining the first confirmation of shoot budforming roots in seven Brazilian tropical forest species, to verify the reserve compounds present in those roots and to determine the mode of origin of shoot buds on roots in two of the study species, Mollinedia schottiana and Machaerium stipitatum.

\section{Materials and methods}

Portions of shoot bud-forming underground systems were collected from a remnant of semideciduous mesophyte forest in Campinas, São Paulo State, Brazil. Fires have been part of the history of disturbances in this forest remnant. Penha (1998) surveyed those tree species that propagate vegetatively from shoot bud-forming roots in this collection area. Twelve species have been studied in the present survey, from which seven were selected for the present study because of their wide distribution in the survey. These were Bauhinia forficata Link (Caesalpiniaceae), Centrolobium tomentosum Guill. ex Benth. (Fabaceae) (Fig. 1), Esenbeckia febrifuga (St.Hil.) Juss. ex Mart. (Rutaceae), Inga laurina (Sw.) Willd. (Mimosaceae), Lonchocarpus cultratus (Vell.) A.M.G.Azevedo \& H.C.Lima (Fabaceae) (Fig. 2), Machaerium stipitatum (DC.) Vog. (Fabaceae) (Fig. 3) and Mollinedia schottiana Perk. (Monimiaceae) (Fig. 4). Penha (1998) discussed 
community characteristics of these species with vegetative propagation potential from shoot buds on roots. Root segments of approximately 20 $\mathrm{cm}$ long and $0.9 \mathrm{~cm}$ in diameter of Machaerium stipitatum were washed and planted horizontally in plastic boxes containing sand and retained inside a greenhouse until buds had sprouted.

The anatomical study to confirm the root structure was carried out by fixing the fragments of the shoot-bearing underground systems in $50 \%$ FAA (Sass 1951). Sections were cut at $60-\mu \mathrm{m}$ thickness on a sliding microtome, cleared in $20 \%$ sodium hypochlorite, washed in distilled water, stained with safranin-astra blue (Gerlach 1969), dehydrated in ethyl alcohol series and 50 and $100 \%$ butyl acetate and mounted with synthetic resin.

Sections of non-fixed root samples were cut at $60-\mu \mathrm{m}$ thickness on a sliding microtome for histochemical tests. Iodide zinc chloride was used to detect starch (Strasburger 1913), Sudan IV for fatty substances (Jensen 1962), aniline blue black for total proteins (Fisher 1968) and ruthenium red for pectic substances (Johansen 1940).

Anatomical studies for identification of the origin of shoot primordia and their early development were carried out by fixing bud samples from field-collected roots and root cuttings in 50\% FAA (Sass 1951 ) or in Karnovsky solution (Karnovsky 1965). Samples fixed in $50 \%$ FAA were dehydrated in ethyl alcohol series, embedded in paraffin and sectioned (11-13 $\mu \mathrm{m}$ thick) on a rotary microtome (Sass 1951). Sections were stained with basic fuchsin-astra blue (Roeser 1972). Samples fixed in Karnovsky solution were dehydrated in ethyl alcohol series, embedded with glycol methacrylate resin and sectioned (5 $\mu \mathrm{m}$ thick) on a rotary microtome. Sections were stained with toluidine blue O (Sakai 1973) or with basic fuchsin-astra blue (Alves de Brito and Alquini 1996). Slides of prepared material were mounted with synthetic resin.

To perform the scanning electronic microscope studies, fragments of Machaerium stipitatum shoot buds were fixed in Karnovsky solution (Karnovsky 1965), dehydrated in ethyl alcohol series, dried to the critical point, mounted on aluminium stubs and sputter-coated with 30-40 nm of gold. Observations and micrographs were made with a DSM 940A Zeiss scanning microscope at $5 \mathrm{kV}$.

\section{Results}

The anatomical study of the shoot bud-forming underground systems of seven tree species confirmed a true root-like structure (Figs 5, 6), as the primary xylem of the vascular cylinder had centripetal maturation (exarch xylem). All the roots were protostelic but the number of protoxylem groups varied among them.

Starch storage in all roots was confined mostly to axial and ray parenchyma cells of the xylem and phloem.

The anatomical study showed that bud primordia of Mollinedia schottiana were located peripherally (Fig. 7) and that the vascular connection, which each developed with the root cambium, was acropetal. These adventitious buds formed asynchronously.

In field-collected roots of Machaerium stipitatum, buds were seen to have originated from proliferation of parenchyma between the secondary phloem and periderm, presumably arising as a consequence of division of residual pericycle cells. Shoot buds on roots originated from the meristematic tissue located peripherally (Fig. 8) in proliferated pericycle (Esau 1977) and, therefore, well below the periderm. Buds developed vascular connections with the root through a combination of acropetal and basipetal differentiation of the vascular elements. Each bud contained several leaf primordia which became visible on the root surface after rupture of the periderm (Fig. 8).

The origin of shoot buds formed on root cuttings (Figs 9-12) followed the same pattern as those obtained from the field-collected roots (Fig. 8); that is, pericycle proliferation always preceded differentiation of bud primordia. In a similar way to that under field conditions, the shoot buds originated from meristematic areas in the periphery of this proliferated pericycle (Fig. 10), and as they developed they established vascular connections with the root by acropetal and basipetal differentiation of vascular tissues (Figs 11, 12).

Lateral roots formed on root cuttings also carried the potential to eventually initiate shoot buds, despite being of smaller diameter than the main root and only at an early stage of their secondary growth. The anatomical structure of the lateral root, in regions of the root where buds were not located, was characterised by the presence of a periderm overlying two or three layers of parenchyma cells derived from the pericycle. Under the primary lignified phloem lay the secondary phloem, the vascular cambium, the secondary xylem and the primary xylem. By comparing the anatomical structure of the lateral roots formed by the cuttings in the sectors without and with buds (Figs 11, 12), it was possible to observe that the parenchyma tissue responsible for the adventitious bud initiation had clearly resulted from division of the pericycle. Wide phloem rays were common beneath each newly formed bud (Figs 11, 12). With further development, shoot buds emerged asynchronously from the root surface after rupture of the periderm (Figs 9, 10).

\section{Discussion}

Occurrence of specialised shoot bud-forming roots has been observed to occur in many tree species in Brazilian forest fragments (Castellani and Stubblebine 1993; Penha 1998), but these underground systems have only rarely been analysed anatomically to confirm their true root structure.

Rizzini and Heringer (1962) described specialised shootforming roots as long, located parallel to the soil surface and characterised anatomically by a central portion without a true pith and centripetal maturation in the primary xylem. These features were also observed here in the underground systems of the seven species analysed in our study, confirming the presence of shoot bud-forming roots in tree species from the Brazilian tropical forest. Sandberg (1951) found no anatomical difference in roots from different parts of the Populus tremuloides root system that could distinguish certain roots as strictly regenerative of shoots. Although the anatomical differences between shoot-forming and normal roots have not been analysed in this study, all roots were located superficially in the soil and had predominantly starch reserves. Bowen and Pate (1993) observed the relationship between the root starch reserves and shoot bud development in root crowns of Stirlingia latifolia and found 

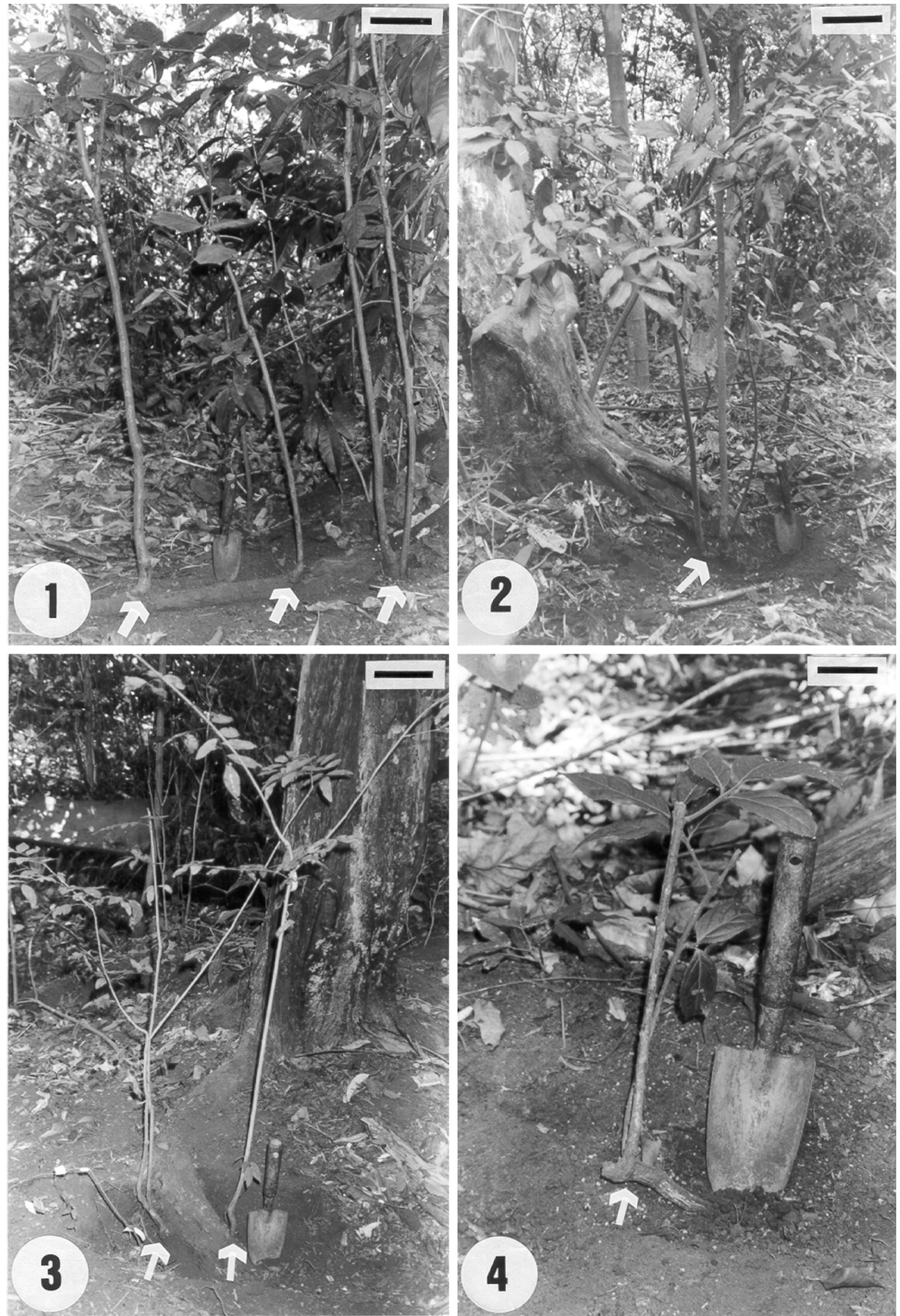

Figs 1-4. Shoot sprouts from horizontal roots. Fig. 1. Centrolobium tomentosum $($ scale $=18.0 \mathrm{~cm})$. Fig. 2. Lonchocarpus cultratus $(\mathrm{scale}=18.0 \mathrm{~cm})$. Fig. 3. Machaerium stipitatum $(\mathrm{scale}=14.8 \mathrm{~cm})$. Fig. 4 . Mollinedia schottiana $($ scale $=4.0 \mathrm{~cm})$. Root sprouts are indicated by arrows. 

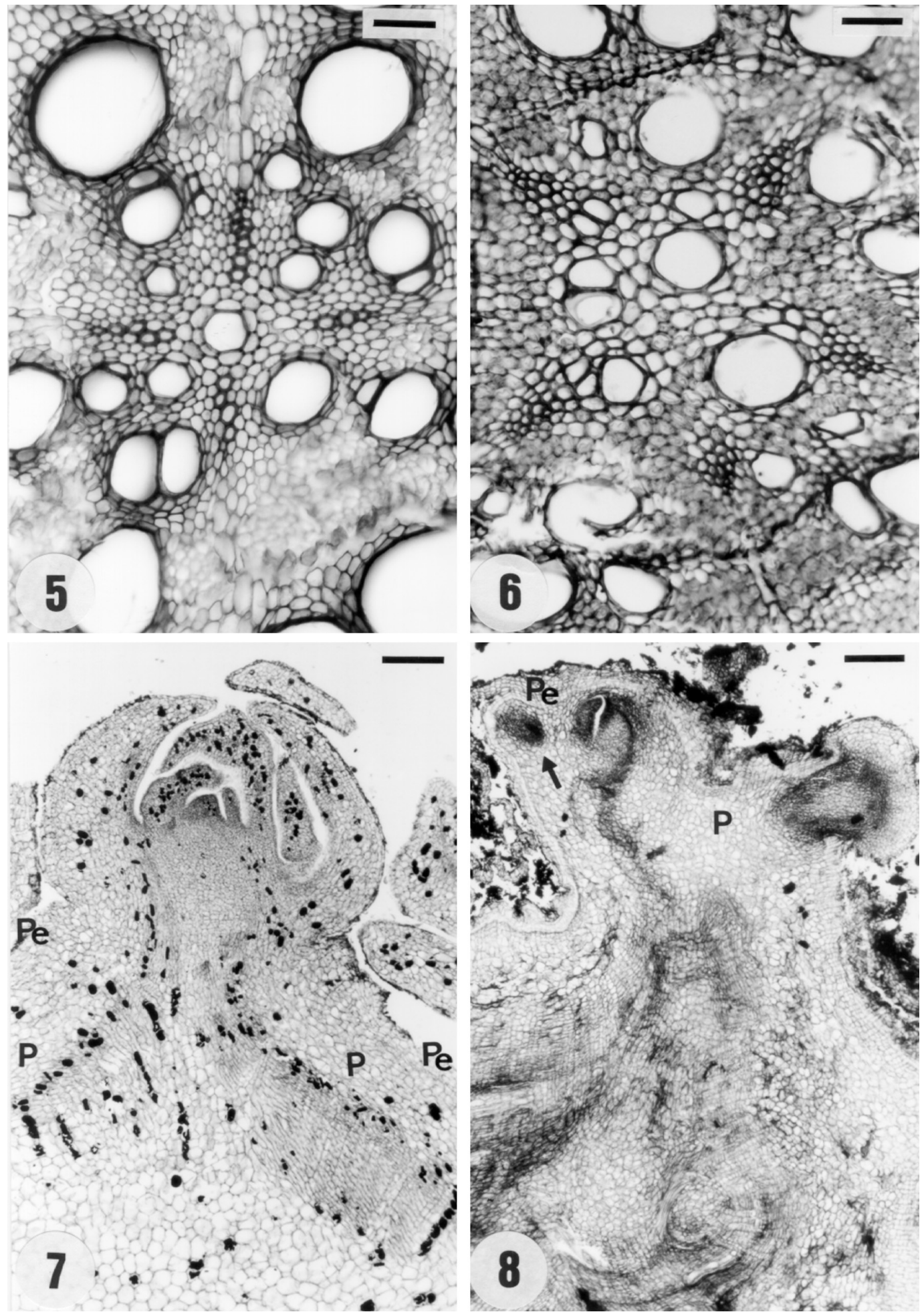

Figs 5-8. Detail of vascular cylinder of shoot bud-forming roots, showing the number of protoxylem groups in crosssection and shoot buds of field-collected roots in longitudinal section. Fig. 5. Tetrarch root of Lonchocarpus cultratus $($ scale $=57.5 \mu \mathrm{m})$. Fig. 6. Pentarch root of Machaerium stipitatum $($ scale $=57.5 \mu \mathrm{m})$. Fig. 7. Mollinedia schottiana shoot bud located peripherally and its vascular connection with the root cambium (scale $=310.5 \mu \mathrm{m}$ ). Fig. 8. Machaerium stipitatum shoot bud primordia (arrow) formed from proliferated pericycle. (scale $=310.5 \mu \mathrm{m}$ ). $\mathrm{Pe}=$ periderm, $\mathrm{P}=$ proliferated pericycle. 

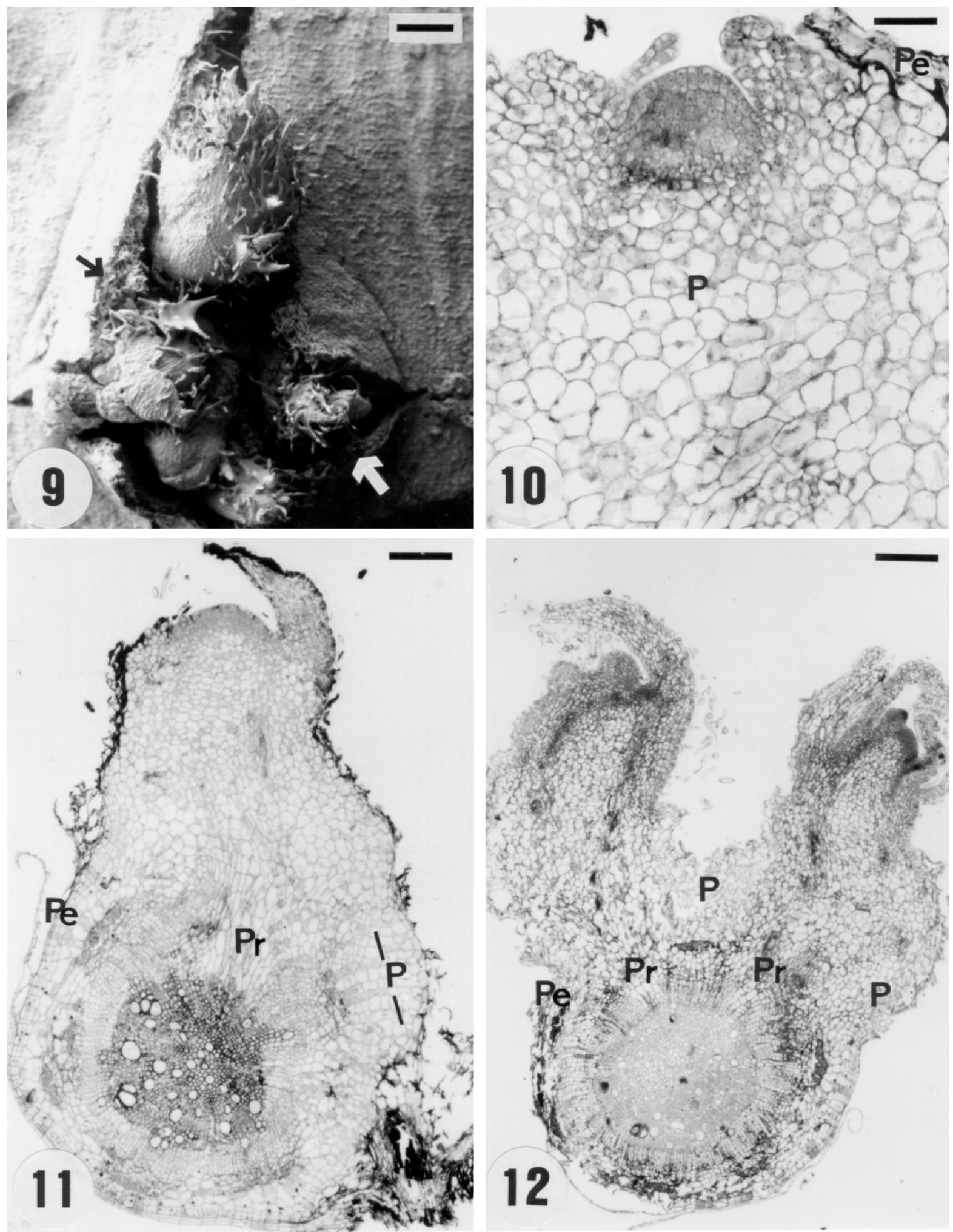

Figs 9-12. Reparative buds of Machaerium stipitatum root cuttings. Fig. 9. Electron micrograph of buds breaking the root periderm (arrows) $($ scale $=200 \mu \mathrm{m}$ ). Figs 10 -12 . Cross-sections of lateral roots showing bud primordia originated from the proliferated pericycle $($ scale $=57.5,221.0,364.5 \mu \mathrm{m}$, respectively). $\mathrm{Pe}=$ periderm; $\mathrm{Pr}=$ phloem ray, $\mathrm{P}=$ pericycle. 
that starch concentration in the root cortex declined sharply during the first months after a burn and that this decline coincided with the production of shoots from the root stock. Bell et al. (1996) presented similar evidence that certain features of the anatomy, organography and reserve status of a range of species of Epacridaceae were correlated with fireresponse strategy. According to these authors, the species that survive and reproduce vegetatively after fire by forming shoot buds on their underground systems (resprouters) have a fairly branched and developed root system and high starch reserves, whereas the root systems of species killed by fire (seeders) are less tap-rooted and show little or no accumulation of starch. The latter property relates to a lower intensity of development of xylem parenchyma rays in seeders than resprouters.

It is shown anatomically here that Mandevilla velutina, a Brazilian savanna species subject to fire damage, stores considerable amounts of starch in its roots and that this characteristic may be related to its shoot bud-forming capacity (Appezzato-da-Glória and Estelita 1995). One can assume that the same reserve compounds present in the other species studied are also available for the successful sprouting of shoot buds after disturbance.

It is already known (e.g. see Peterson 1975) that the sites at which buds initiate on roots may vary widely between species, and several classes of root tissue have been implicated in the formation of bud primordia. Consequently, developmental patterns vary considerably, depending on the root region where the bud initiates (Peterson 1975). In our study of field-collected roots and artificially propagated root cuttings of Machaerium stipitatum, buds were shown to originate in the proliferated pericycle, just as has been shown elsewhere for field-collected roots of Euphorbia esula (Bakshi and Coupland 1959), Araucaria cunninghamii (Burrows 1990) and Sassafras albidum (Bosela and Ewers 1997).

Wittrock (1884), quoted by Raju et al. (1966), stated that a distinction should be made between shoot bud production on uninjured root systems (additional buds) and bud development occurring only after injury from fire or cutting (reparative buds). Constitutive (non-reparative) buds form during the early growth of roots of undamaged plants, tend to be endogenous in origin and are mostly subtended by bud traces that are contiguous with the centre of a root. By contrast, reparative buds form de novo in response to senescence, injuries or other types of disturbance of the root and may therefore be initiated at any period of root secondary growth. The latter class of bud primordia are usually exogenous and in their early development show absence of vascular traces (Bosela and Ewers 1997). Sandberg (1951) found that the shoot buds on roots of Populus tremuloides are constitutive and of endogenous origin from the pericycle. Thus, several growth rings are generated along the bud trace and this results in continuity of root secondary growth after the shoot bud has sprouted.
Mollinedia schottiana and Machaerium stipitatum shoot buds were reparative (epicormic) in that they were exogenous in origin. They were not associated with secondary xylem and lacked bud traces in their early development.

Bosela and Ewers (1997) found that both constitutive and reparative bud formation are found in Sassafras albidum root systems. However, the initiation of buds in Araucaria cunninghamii does not normally occur unless disturbance takes place (Burrows 1990).

Mollinedia schottiana and Machaerium stipitatum shoot buds on roots were observed in a forest fragment affected by frequent fires. Generally, the formation and development of these buds are related to environmental disturbances that cause alterations in the aerial part or in the root system of the plant (Rizzini and Heringer 1966; Lacey and Johnston 1990). In regions subject to periodic fire or other types of disturbance where whole aboveground parts of a shoot may be killed, the initiation of shoots from buds formed on underground systems clearly represents a valuable characteristic for survival of a species and the general reestablishment of plant cover in the system (Lacey and Johnston 1990).

The occurrence of reparative shoots on roots, as verified in the present study, may result in the formation of populations with aggregated spatial distribution generally attributed to the sexual reproductive system (Penha 1998). Therefore, the capacity of the plants to propagate vegetatively from shoot buds on roots may modify many aspects in the discussion of community dynamics and the management and recuperation procedures in Brazilian forest fragments.

\section{Acknowledgments}

Our thanks go to Dr L. A. F. Matthes, scientific researcher at the Centro de Horticultura III, Instituto Agronômico de Campinas, and to Professor E. W. Kitajima, coordinator of NAP-MEPA at the Escola Superior de Agricultura 'Luiz de Queiroz', Universidade de São Paulo. This research was funded by financial support from the FAPESP (97/3554-2) and CNPq. We also thank the anonymous referees for constructive criticism of an earlier version of the manuscript.

\section{References}

Alves de Brito CJF, Alquini Y (1996) A new method for staining botanical material embedded in glycol methacrylate (GMA). Arquivos de Biologia e Tecnologia 39, 949-951.

Appezzato-da-Glória B, Estelita MEM (1995) Caracteres anatômicos da propagação vegetativa de Mandevilla illustris (Vell.) Woodson e de M. velutina (Mart. ex Stadelm.) Woodson-Apocynaceae. In 'Anais do IX Congresso da Sociedade Botânica de São Paulo'. (Ed. MRP Noronha) pp. 5-13. (Sociedade Botânica de São Paulo: São Paulo)

Baird JH, Dute RR, Dickens R (1992) Ontogeny, anatomy, and reproductive biology of vegetative reproductive organs of Diodia virginiana L. (Rubiaceae). International Journal of Plant Sciences 153, 320-328. 
Bakshi TS, Coupland RT (1959) An anatomical study of the subterranean organs of Euphorbia esula in relation to its control. Canadian Journal of Botany 37, 613-620.

Bell TL, Pate JS, Dixon KW (1996) Relations between fire response, morphology, root anatomy and starch distribution in south-west Australian Epacridaceae. Annals of Botany 77, 357-364.

Bosela MJ, Ewers FW (1997) The mode of origin of root buds and root sprouts in the clonal tree Sassafras albidum (Lauraceae). American Journal of Botany 84, 1466-1481.

Bowen BJ, Pate JS (1993) The significance of root starch in post-fire shoot recovery of the resprouter Stirlingia latifolia R.B (Proteaceae). Annals of Botany 72, 7-16.

Burrows GE (1990) Anatomical aspects of root bud development in hoop pine (Araucaria cunninghamii). Australian Journal of Botany 38, 73-78.

Castellani TT, Stubblebine WH (1993) Sucessão secundária inicial em mata tropical mesófila, após perturbação por fogo. Revista Brasileira de Botânica 16, 181-203.

Esau K (1977) 'Anatomy of seed plants.' 2nd Edn. (John Wiley \& Sons: New York)

Fisher DB (1968) Protein staining of ribboned epon sections for light microscopy. Histochemie 16, 92-96.

Gerlach G (1969) 'Botanische microtechnik, eine einführung.' (Georg Thieme: Stuttgart)

Jensen WA (1962) 'Botanical histochemistry.' (WH Freeman: San Francisco)

Johansen DA (1940) 'Plant microtechnique.' (McGraw-Hill Book Co.: New York)

Karnovsky MJ (1965) A formaldehyde-glutaraldehyde fixative of high osmolality for use in electron microscopy. Journal of Cell Biology 27, 137-138.

Lacey CJ, Johnston RD (1990) Woody clumps and clumpwoods. Australian Journal of Botany 38, 299-334.

Penha AS (1998) Propagação vegetativa de espécies arbóreas a partir de raízes gemíferas: representatividade na estrutura fitossociológica e descrição dos padrões de rebrota de uma comunidade florestal. Dissertação de Mestrado, Instituto de Biologia, Universidade Estadual de Campinas, Brasil.
Peterson RL (1975) The initiation and development of root buds. In 'The development and function of roots'. (Eds JG Torrey, DT Clarkson) pp. 125-161. (Academic Press: London)

Polowick PL, Raju MVS (1982) The origin and development of root buds in Asclepias syriaca. Canadian Journal of Botany 60, 2119-2125.

Raju MVS, Coupland RT, Steeves TA (1966) On the occurrence of root buds on perennial plants in Saskatchewan. Canadian Journal of Botany 44, 33-37.

Rizzini CT, Heringer EP (1961) Underground organs of plants from some southern Brazilian savannas, with special reference to the xylopodium. Phyton 17, 105-124.

Rizzini CT, Heringer EP (1962) Studies on the underground organs of trees and shrubs from some southern Brazilian savannas. Anais da Academia Brasileira de Ciências 34, 235-247.

Rizzini CT, Heringer EP (1966) Estudo sobre os sistemas subterrâneos difusos de plantas campestres. Anais da Academia Brasileira de Ciências 38, 85-112.

Roeser KR (1972) Die nadel der schwarzkiefer-massen produkt und kunstwert der natur. Mikrokosmos 61, 33-36.

Rood SB, Hillman C, Sanche T, Mahoney J (1994) Clonal reproduction of riparian cottonwoods in southern Alberta. Canadian Journal of Botany 72, 1766-1774.

Sakai WS (1973) Simple method for differential staining of paraffin embedded plant material using toluidine blue O. Stain Technology 48, 247-249.

Sandberg D (1951) The regeneration of quaking aspen by root suckering. Masters Thesis, School of Forestry, University of Minnesota, USA.

Sass JE (1951) 'Botanical microtechnique.' (Iowa State University Press: Ames)

Strasburger E (1913) 'Handbook of practical botany.' (George Allen: London)

Manuscript received 3 April 2001, accepted 20 June 2001 